Original article

\title{
Comparative dynamic analysis of morbidity in various age groups in Russian Federation
}

\author{
Vera A. Pogodina ${ }^{1}$, Evgeniy A. Babenko ${ }^{2}$, Natalia A. Gusel'nikova ${ }^{2}$, Anatoliy I. Babenko ${ }^{2}$ \\ ${ }^{1}$ Novosibirsk State Medical University, Novosibirsk, Russia \\ ${ }^{2}$ Research Institute for Complex Problems of Hygiene and Occupational Diseases, Novokuznetsk, Kemerovo Region, Russia
}

Received 2 June 2016, Revised 17 June 2016, Accepted 8 July 2016

(C) 2016, Pogodina V.A., Babenko E.A., Gusel'nikova N.A., Babenko A.I.

(C) 2016, Russian Open Medical Journal

Abstract: Aim of the study - To perform a comparative analysis of morbidity rates in children aged 0-14 years and 15-17 years, in population older than 18 years, in women older than 55 years and men older than 60 years in Russian Federation based on the data of healthcare visits in 2004-2014.

Material and Methods - Data in statistical yearbooks published by Rosstat was studied by calculating mean morbidity rates and their amplitude through the years and by comparing that using deterministic factor analysis.

Results - Increase of morbidity rate was observed in (1) children aged 0-14 years by $665.9 \%$ (1667.0 to $2332.9 \%$ ) with mean rate of $2000.0 \pm 333.0 \%$, in children aged $15-17$ years by $358.6 \%$ o (1060.2 to $1418.8 \%$ ) with mean rate of $1245.8 \pm 185.6 \%$, difference of $307.3 \%$ o and amplitude of $147.4 \%$; (2) in population older than 18 years by $49.3 \%$ o (515.4 to $564.7 \%$ o) with mean rate of $541.8 \pm 26.4 \%$, and in women older than 55 years and men older than 60 years by $42.4 \%$ o (2039.9 to $2082.3 \%$ o) with mean rate of $2054.5 \pm 27.9 \%$, difference of $6.9 \%$ and amplitude of $1.5 \%$. Specific characteristics of morbidity in various age groups were determined.

Conclusion - Rate of healthcare visits in Russian Federation was higher for children aged 0-14 years and population older than 18 years. Morbidity increase rate was higher in children aged 0-14 years and women older than 55 years and men older than 60 years. Structural differences in disease groups were detected, which may be taken into account when planning preventive measures according to population age.

Keywords: morbidity, population age groups, dynamic analysis

Cite as Pogodina VA, Babenko EA, Gusel'nikova NA, Babenko Al. Comparative dynamic analysis of morbidity in various age groups in Russian Federation. Russian Open Medical Journal 2016; 5: e0307.

Correspondence to Dr Vera A. Pogodina. Phone: 8-913-003-69-61. E-mail: vera-pogodina@yandex.ru

\section{Introduction}

Morbidity in various age groups has some specific qualities, which are defined not only by anatomical and physiological differences, but also by possibility of receiving medical and prophylactic care, by lifestyle and living conditions, which are related to levels of social and economic development in regions of Russian Federation [1]. The aforementioned problem exists in other countries. Foreign researchers in field of healthcare organization also confirm that lifestyle of population lies in foundation of national health, and health condition in various age groups allows to organize medical care and prophylaxis with specific differences among them taken into account [2]. Sources indicate that while health of various age groups in Russian Federation tends to deteriorate [3], such negative age-related trends are observed in other countries too, including the countries of European Union [4]

To a great extent, basis of potential future health is determined by childhood. Unfavorable tendencies in children's health are observed in Russian Federation during the last decades, which are characterized by increase in incidence of functional disorders and chronic diseases and decline in physical development rate [5]. According to British researchers, children in other countries also tend to suffer from negative changes in health [6].
The degree of health decline in population allows to represent rates of incidence, while its structural analysis allows to define priority prophylactic measures for organizing healthcare. Dutch researchers state that it is necessary to study morbidity in all groups of country's citizens to observe demographic trends and monitor progress towards national goals in healthcare development [7]. Organization of preventive medicine based on differences in health of various age groups in Russian Federation presents itself as a relevant issue.

The aim of this study was to perform a comparative dynamic analysis of general morbidity rates in children aged 0-14 and 15-17 years, in population older than 18 years, in women older than 55 years and men older than 60 years in Russian Federation based on healthcare visits and requests in 2004-2014.

\section{Material and Methods}

\section{Study of statistical yearbooks}

Evaluation of general morbidity in Russian Federation based on healthcare visits and requests was performed through consecutive study of data on population of different ages in state-published statistical yearbooks (Rosstat) for 11 years (2004-2014) [8, 9]. 
Table 1. Comparative dynamic analysis of general morbidity of children aged 0-14 years and 15-17 years in Russian Federation through 2004-2014

\begin{tabular}{|c|c|c|c|c|}
\hline \multirow[b]{2}{*}{ Year } & \multicolumn{2}{|c|}{ Rate (per 1000 children) * } & \multicolumn{2}{|c|}{ Growth / decrease rate (\%) ** } \\
\hline & Children aged $0-14$ years & Children aged $15-17$ years & $\begin{array}{c}\text { Children aged 0-14 } \\
\text { years }\end{array}$ & $\begin{array}{c}\text { Children aged } 15-17 \\
\text { years }\end{array}$ \\
\hline 2004 & 1667.0 & 1060.2 & 2.0 & 1.9 \\
\hline 2005 & 1717.7 & 1126.7 & 3.0 & 6.3 \\
\hline 2006 & 1775.1 & 1183.8 & 3.3 & 5.1 \\
\hline 2007 & 1829.0 & 1235.5 & 3.0 & 4.4 \\
\hline 2008 & 1827.1 & 1249.4 & -0.1 & 1.1 \\
\hline 2009 & 1943.9 & 1306.5 & 6.4 & 4.6 \\
\hline 2010 & 1886.9 & 1357.6 & -2.9 & 3.9 \\
\hline 2011 & 1912.7 & 1411.3 & 1.4 & 4.0 \\
\hline 2012 & 1890.1 & 1431.3 & -1.2 & 1.4 \\
\hline 2013 & 2332.9 & 1418.8 & 23.4 & -0.9 \\
\hline 2014 & 2332.9 & 1418.8 & 23.4 & -0.9 \\
\hline $\begin{array}{l}\text { Mean value for 2004-2014 period, } \\
M \pm S D\end{array}$ & $2000.0 \pm 333.0$ & $1245.8 \pm 185.6$ & 40.0 & 33.8 \\
\hline
\end{tabular}

$\mathrm{M} \pm \mathrm{SD}$, mean with standard deviation. ${ }^{*}-$ value taken from official statistical yearbooks published by Rosstat; ${ }^{* *}-$ calculated by authors.

Table 2. Comparative dynamic analysis of general morbidity in population older than 0-14 years and women older than $\mathbf{5 5}$ years and men older than $\mathbf{6 0}$ years in Russian Federation through 2004-2014

\begin{tabular}{|c|c|c|c|c|}
\hline \multirow[b]{2}{*}{ Year } & \multicolumn{2}{|c|}{ Rate (per 1000 population) * } & \multicolumn{2}{|c|}{ Growth / decrease rate (\%) ** } \\
\hline & $\begin{array}{c}\text { Population older than } \\
18 \text { years }\end{array}$ & $\begin{array}{c}\text { Women older than } 55 \text { years } \\
\text { and men older than } 60 \\
\text { years }\end{array}$ & $\begin{array}{l}\text { Population older } \\
\text { than } 18 \text { years }\end{array}$ & $\begin{array}{c}\text { Women older than } 55 \text { years } \\
\text { and men older than } 60 \\
\text { years }\end{array}$ \\
\hline 2004 & 515.4 & - & 2.1 & - \\
\hline 2005 & 526.4 & - & 2.1 & - \\
\hline 2006 & 537.3 & - & 2.1 & - \\
\hline 2007 & 548.2 & - & 2.0 & - \\
\hline 2008 & 559.1 & - & 2.0 & - \\
\hline 2009 & 568.2 & 2039.9 & 1.6 & 1.0 \\
\hline 2010 & 551.0 & 2026.6 & -3.0 & -0.7 \\
\hline 2011 & 554.6 & 2043.3 & 0.7 & 0.8 \\
\hline 2012 & 559.1 & 2064.5 & 0.8 & 1.0 \\
\hline 2013 & 564.7 & 2082.3 & 1.0 & 0.9 \\
\hline 2014 & 564.7 & 2082.3 & 1.0 & 0.9 \\
\hline Mean value for $2004-2014$ period, $M \pm S D$ & $541.8 \pm 26.4$ & $2054.5 \pm 27.9$ & 9.6 & 2.1 \\
\hline
\end{tabular}

$\mathrm{M} \pm \mathrm{SD}$, mean with standard deviation. * - value taken from official statistical yearbooks published by Rosstat; ${ }^{* *}-$ calculated by authors.

\section{Dynamic analysis}

Absolute numerical data on population morbidity grouped by age (based on Rosstat yearbooks) was put in a dynamic range and, by calculating mean values for each group, transformed to relative parameters (extensive and intensive), which were characterized and compared against each other. Extensive parameter is a structural share of certain group of diseases (ICD-10) [10] in population, while the intensive parameter is an incidence of disease in population. Structural and logical relationship between those parameters was analyzed and interpreted.

\section{Statistical analysis}

Mean arithmetic values and their fluctuations through the years were calculated and compared by deterministic factor analysis [11] using Microsoft Office Excel 2010 and SPSS 11.5 software.

\section{Results}

In order to deepen the understanding of diseases' incidence and possible improvement of healthcare management levels of general morbidity and priority disease classes were studied among the children aged $10-14$ years and $15-17$ years, population older than 18 years and women older than 55 years together with men older than 60 years in Russian Federation through 2004-2014 time period.

It was established that morbidity rate increased:

1) in children aged 0-14 years by $40.0 \%$ (from 1667.0 to $2332.9 \%$ ) with mean value of $2000.0 \pm 333.0 \%$ and average increase of $4.0 \%$ per year, in children aged $15-17$ years by $33.8 \%$ (from 1060.2 to $1418.8 \%$ ) with mean value of $1245.8 \pm 185.6 \%$ o and average increase of $3.4 \%$ per year (Table 1 );

2 ) in population older than 18 years by $9.6 \%$ (from 515.4 to $564.7 \%$ o) with mean value of $541.8 \pm 26.4 \%$ and average growth of $1.0 \%$ per year, while in women older than 55 years and men older than 60 years it increased by $2.1 \%$ (from 2039.9 to $2082.3 \%$ ) with mean value of $2054.5 \pm 27.9 \%$ and average increase of $0.2 \%$ per year (Table 2). 
Table 3. Comparative characteristics of morbidity rate and structure of children aged 0-14 years and $\mathbf{1 5}-\mathbf{1 7}$ years in Russian Federation stratified by disease classes (mean values for 2004-2014 period)

\begin{tabular}{|c|c|c|c|c|c|c|}
\hline \multirow[t]{2}{*}{$\begin{array}{l}\text { Class of disease } \\
\text { (ICD-10) }\end{array}$} & \multicolumn{2}{|c|}{ Incidence per 1000 children * } & \multicolumn{2}{|c|}{$\begin{array}{l}\text { Amplitude of variance by years } \\
(\% \circ)^{* *}\end{array}$} & \multicolumn{2}{|c|}{ Percentage $(\%)^{* *}$} \\
\hline & $\begin{array}{l}\text { Children aged } \\
0-14 \text { years }\end{array}$ & $\begin{array}{l}\text { Children aged } \\
15-17 \text { years }\end{array}$ & $\begin{array}{c}\text { Children aged } \\
0-14 \text { years }\end{array}$ & $\begin{array}{l}\text { Children aged } \\
15-17 \text { years }\end{array}$ & $\begin{array}{l}\text { Children aged } \\
0-14 \text { years }\end{array}$ & $\begin{array}{l}\text { Children aged } \\
15-17 \text { years }\end{array}$ \\
\hline $\begin{array}{l}\text { Certain infectious and parasitic diseases } \\
\text { (class I) }\end{array}$ & 86.6 & 41.2 & \pm 8.2 & \pm 3.1 & 5.0 & 3.4 \\
\hline Neoplasms (class II) & 4.1 & 3.7 & \pm 0.8 & \pm 0.8 & 0.2 & 0.3 \\
\hline $\begin{array}{l}\text { Diseases of the blood and blood-forming } \\
\text { organs and certain disorders involving the } \\
\text { immune mechanism (class III) }\end{array}$ & 17.8 & 7.9 & \pm 2.6 & \pm 1.8 & 1.0 & 0.6 \\
\hline $\begin{array}{l}\text { Endocrine, nutritional and metabolic } \\
\text { diseases (class IV) }\end{array}$ & 17.1 & 25.4 & \pm 1.7 & \pm 1.0 & 1.0 & 2.1 \\
\hline Diseases of the nervous system (class VI) & 39.2 & 34.9 & \pm 3.9 & \pm 6.6 & 2.3 & 2.9 \\
\hline Diseases of the eye and adnexa (class VII) & 58.0 & 53.7 & \pm 3.2 & \pm 8.4 & 3.3 & 4.4 \\
\hline $\begin{array}{l}\text { Diseases of the ear and mastoid process } \\
\text { (class VIII) }\end{array}$ & 51.0 & 29.6 & \pm 3.8 & \pm 6.3 & 2.9 & 2.4 \\
\hline Diseases of the circulatory system (class IX) & 8.9 & 16.0 & \pm 0.8 & \pm 2.1 & 0.5 & 1.3 \\
\hline Diseases of the respiratory system (class X) & 1096.1 & 600.9 & \pm 120.4 & \pm 109.9 & 63.1 & 49.3 \\
\hline Diseases of the digestive system (class XI) & 84.2 & 67.8 & \pm 2.8 & \pm 10.0 & 4.9 & 5.6 \\
\hline $\begin{array}{l}\text { Diseases of the skin and subcutaneous } \\
\text { tissue (class XII) }\end{array}$ & 91.4 & 79.2 & \pm 5.8 & \pm 8.1 & 5.3 & 6.5 \\
\hline $\begin{array}{l}\text { Diseases of the musculoskeletal system and } \\
\text { connective tissue (class XIII) }\end{array}$ & 38.2 & 56.6 & \pm 1.7 & \pm 6.2 & 2.2 & 4.6 \\
\hline $\begin{array}{l}\text { Diseases of the genitourinary system (class } \\
\text { XIV) }\end{array}$ & 30.1 & 58.0 & \pm 1.9 & \pm 7.3 & 1.7 & 4.8 \\
\hline $\begin{array}{l}\text { Congenital malformations, deformations } \\
\text { and chromosomal abnormalities (class XVII) }\end{array}$ & 10.4 & 3.4 & \pm 1.7 & \pm 0.4 & 0.6 & 0.3 \\
\hline $\begin{array}{l}\text { Injury, poisoning and certain other } \\
\text { consequences of external causes (class XIX) }\end{array}$ & 104.6 & 140.5 & \pm 4.4 & \pm 26.9 & 6.0 & 11.5 \\
\hline Total $* *$ & 2000.0 & 1245.8 & \pm 333.0 & \pm 185.6 & 100.0 & 100.0 \\
\hline
\end{tabular}

* - value taken from official statistical yearbooks published by Rosstat; ** - calculated by authors.

Among different disease classes the highest incidence is observed in the following groups:

1) in children aged 0-14 years: diseases of the respiratory system $(1096.1 \% \circ)$, injuries and poisoning $(104.6 \%)$, diseases of the skin and subcutaneous tissue $(91.4 \%$ ), which held the top three positions, while infectious and parasitic diseases (86.6\%) and diseases of the digestive system $(84.2 \%$ ), holding fourth and fifth positions, were also notable; aforementioned classes include $84,3 \%$ of all disease cases; in children aged 15-17 years: diseases of the respiratory system (600.9\%o), injuries and poisoning (140.5\%o), diseases of the skin and subcutaneous tissue $(79.2 \%)$, which held the top three positions, while diseases of the digestive system $(67.8 \%$ ) and diseases of the genitourinary system $(58.0 \%$ ) were also notable, holding fourth and fifth positions; aforementioned classes include $77.7 \%$ of all disease cases (Table 3 ).

2 ) in population older than 18 years: diseases of the respiratory system (154.1\%o), injuries and poisoning $(86.1 \%$ ), complications of pregnancy and childbirth (77.9\%), which held the top three positions, while diseases of the genitourinary system $(50.0 \%)$ and diseases of the skin and subcutaneous tissue (40.0\%o), holding fourth and fifth positions, were also notable; aforementioned classes include $67.5 \%$ of all disease cases; in women older than 55 years and men older than 60 years: diseases of the respiratory system (126.3\%o), injuries and poisoning $(73.2 \%$ ), diseases of the circulatory system (56.3\%o), which held the top three positions, while diseases of the eye and adnexa (41.9\%) and diseases of the skin and subcutaneous tissue $(38.5 \%$ ) were also notable, holding fourth and fifth positions; aforementioned classes include $64.9 \%$ of all disease cases (Table 4).
Other classes of diseases in studied population of Russian Federation had lesser incidence and their comparison was of little statistical interest.

\section{Discussion}

Russian researchers in fields of social science, economics and medicine, including "public health and healthcare", state that increase in morbidity rates in population of Russian Federation is observed since 1990, pointing out at certain structural differences in it among various age groups $[12,13]$. Comparison of mean values of morbidity for different disease classes with age taken into account demonstrates characteristics and specifics of disease incidence and health-seeking behavior.

National healthcare development researchers of US National Center for Chronic Disease Prevention and Health Promotion (NCCDPHP) and National Institutes of Health (NIH) in their articles on results of PROMIS research prove that studying rates of morbidity and its structure in population of different age groups facilitates forming of specific preventive practices [14].

As of now, however, foreign scientific papers available in open access do not include information on comparison of morbidity rates and structure in whole population stratified by age in specific countries, but some short messages on disease incidence in certain age groups do exist. Brief reports by authors from various countries include morbidity rate and structure in children, adult and elderly population with different age stratification [15]. That's why it's impossible to compare evaluated morbidity rates between Russian Federation and other countries. 
Table 4. Comparative characteristics of morbidity rate and structure in population older than 18 years and women older than 55 years and men older than 60 years in Russian Federation stratified by disease classes (mean values for 2004-2014 period)

\begin{tabular}{|c|c|c|c|c|c|c|}
\hline \multirow[t]{2}{*}{$\begin{array}{l}\text { Class of disease } \\
\text { (ICD-10) }\end{array}$} & \multicolumn{2}{|c|}{ Incidence per 1000 population * } & \multicolumn{2}{|c|}{$\begin{array}{l}\text { Amplitude of variance by years } \\
(\%)^{* *}\end{array}$} & \multicolumn{2}{|c|}{ Percentage $(\%)^{* *}$} \\
\hline & $\begin{array}{l}\text { Population } \\
\text { older than } 18 \\
\text { years }\end{array}$ & $\begin{array}{c}\text { Women older } \\
\text { than } 55 \text { years and } \\
\text { men older than } \\
60 \text { years }\end{array}$ & $\begin{array}{l}\text { Population } \\
\text { older than } 18 \\
\text { years }\end{array}$ & $\begin{array}{c}\text { Women older } \\
\text { than } 55 \text { years and } \\
\text { men older than } \\
60 \text { years }\end{array}$ & $\begin{array}{l}\text { Population } \\
\text { older than } 18 \\
\text { years }\end{array}$ & $\begin{array}{c}\text { Women older } \\
\text { than } 55 \text { years and } \\
\text { men older than } \\
60 \text { years }\end{array}$ \\
\hline $\begin{array}{l}\text { Certain infectious and parasitic } \\
\text { diseases (class I) }\end{array}$ & 24.6 & 16.6 & \pm 3.4 & \pm 1.3 & 4.1 & 3.2 \\
\hline Neoplasms (class II) & 12.0 & 18.8 & \pm 1.2 & \pm 0.8 & 2.0 & 3.6 \\
\hline $\begin{array}{l}\text { Diseases of the blood and blood- } \\
\text { forming organs and certain } \\
\text { disorders involving the immune } \\
\text { mechanism (class III) }\end{array}$ & 2.5 & 1.6 & \pm 0.2 & \pm 0.2 & 0.4 & 0.3 \\
\hline $\begin{array}{l}\text { Endocrine, nutritional and metabolic } \\
\text { diseases (class IV) }\end{array}$ & 9.3 & 11.5 & \pm 0.7 & \pm 1.5 & 1.5 & 2.2 \\
\hline $\begin{array}{l}\text { Diseases of the nervous system } \\
\text { (class VI) }\end{array}$ & 11.0 & 8.0 & \pm 1.1 & \pm 0.2 & 1.8 & 1.5 \\
\hline $\begin{array}{l}\text { Diseases of the eye and adnexa } \\
\text { (class VII) }\end{array}$ & 29.3 & 41.9 & \pm 1.4 & \pm 0.9 & 4.8 & 8.1 \\
\hline $\begin{array}{l}\text { Diseases of the ear and mastoid } \\
\text { process (class VIII) }\end{array}$ & 20.9 & 28.8 & \pm 2.0 & \pm 0.8 & 3.5 & 5.6 \\
\hline $\begin{array}{l}\text { Diseases of the circulatory system } \\
\text { (class IX) }\end{array}$ & 31.2 & 56.3 & \pm 3.4 & \pm 5.9 & 5.2 & 10.9 \\
\hline $\begin{array}{l}\text { Diseases of the respiratory system } \\
\text { (class X) }\end{array}$ & 154.1 & 126.3 & \pm 9.1 & \pm 9.3 & 25.5 & 24.4 \\
\hline $\begin{array}{l}\text { Diseases of the digestive system } \\
\text { (class XI) }\end{array}$ & 23.3 & 23.3 & \pm 1.3 & \pm 2.3 & 3.8 & 4.5 \\
\hline $\begin{array}{l}\text { Diseases of the skin and } \\
\text { subcutaneous tissue (class XII) }\end{array}$ & 40.0 & 38.5 & \pm 2.1 & \pm 1.2 & 6.6 & 7.4 \\
\hline $\begin{array}{l}\text { Diseases of the musculoskeletal } \\
\text { system and connective tissue (class } \\
\text { XIII) }\end{array}$ & 32.7 & 35.8 & \pm 2.3 & \pm 0.3 & 5.4 & 6.9 \\
\hline $\begin{array}{l}\text { Diseases of the genitourinary } \\
\text { system (class XIV) }\end{array}$ & 50.0 & 37.6 & \pm 3.0 & \pm 1.1 & 8.3 & 7.3 \\
\hline $\begin{array}{l}\text { Pregnancy, childbirth and the } \\
\text { puerperium (class XV) }\end{array}$ & 77.9 & - & \pm 4.1 & - & 12.9 & - \\
\hline $\begin{array}{l}\text { Injury, poisoning and certain other } \\
\text { consequences of external causes } \\
\text { (class XIX) }\end{array}$ & 86.1 & 73.2 & \pm 2.1 & \pm 1.2 & 14.2 & 14.1 \\
\hline Total $(* *)$ & 604.6 & 517.8 & \pm 37.0 & \pm 26.6 & 100.0 & 100.0 \\
\hline
\end{tabular}

* - value taken from official statistical yearbooks published by Rosstat; ** - calculated by authors.

Age differences were observed when comparing morbidity rates in Russian Federation through 2004-2014. Difference in morbidity level was:

1) $307.3 \%$ in children aged $0-14$ years (665.9\%o) and $15-17$ years $(358.6 \%$ ) with amplitude of $147.4 \%$, which is evidence of increasing morbidity in children aged 0-14 years;

2) $6.9 \%$ in population older than 18 years $(49.3 \%$ ) and in women older than 55 years and men older than 60 years $(42.4 \%$ ), with amplitude of $1.5 \%$, which confirms that morbidity rate is higher in population older than 18 years and morbidity growth rate is higher in women older than 55 years and men older than 60 years.

People of various age groups have different lifestyle. Learning activity is dominant in children (0-17 years). In population older than 18 years working and other activity is prevalent. Consequently, certain disease incidence rates will be different.

Main changes in disease incidence in Russian Federation through the studied period are characterized by increase of:
1) congenital malformations (by $67.3 \%$ ), diseases of the blood and blood-forming organs (by 55.6\%), certain infectious and parasitic diseases (by $52.4 \%$ ), diseases of the respiratory system (by $45.2 \%$ ), diseases of the ear and mastoid process (by $42.0 \%$ ), diseases of the digestive system (by 19.5\%), diseases of the skin and subcutaneous tissue (by 13.3\%) in children aged 0-14 years;

2) diseases of the genitourinary system (by $92.7 \%$ ), diseases of the circulatory system (by $79.8 \%$ ), endocrine, nutritional and metabolic diseases (by $48.5 \%$ ), diseases of the musculoskeletal system and connective tissue (by $48.2 \%$ ), injuries and poisonings (by $34.3 \%$ ) in children aged $15-17$ years;

3) diseases of the blood and blood-forming organs (by $36.0 \%$ ), certain infectious and parasitic diseases (by 32.5\%), diseases of the nervous system (by $27.3 \%$ ), diseases of the genitourinary system (by $24.8 \%$ ), diseases of the respiratory system (by $18.0 \%$ ), injuries and poisonings (by $15.0 \%$ ) in population older than 18 years;

4) diseases of the circulatory system (by $80.4 \%$ ), neoplasms (by $56.7 \%$ ), diseases of the eye and adnexa (by $43.0 \%$ ), diseases of the ear and mastoid process (by $37.8 \%$ ), endocrine, nutritional and 
metabolic diseases (by 23.7\%) in women older than 55 years and men older than 60 years.

\section{Conclusion}

Comparative dynamic analysis of general morbidity rates in different age groups of population of Russian Federation through 2004-2014 has determined that health-seeking behavior incidence and growth rate of morbidity is higher in children aged 0-14 years, than in children aged $15-17$ years. Meanwhile, morbidity rate is higher in population older than 18 years, than in women older than 55 years and men older than 60 years. Morbidity growth rate was higher in children aged 0-14 years and in women older than 55 years and men older than 60 years. Differences in incidence of basic disease classes and health-seeking behavior incidence of various age groups were determined, which will allow to improve preventive healthcare.

Conflict of interest: none declared.

\section{References}

1. Okrepilov VV. The development of health economics to improve the quality of life. Ekonomicheskie i sotsial'nye peremeny: fakty, tendentsii, prognoz 2012; 5(23): 33-47. Russian

2. Fransen MP, Rowlands G, Leenaars KEF, Essink-Bot ML. Self-rated literacy level does not explain educational differences in health and disease. Archives of Public Health 2014; 72: 14. (PMID: 24872884) (doi: 10.1186/2049-3258-72-14)

3. Surmach MYu. Quality of life related to health, as the subject matter of sociology of medicine. Sotsiologi 2011; (2): 98-102. Russian

4. Krabbe PF, Tromp N, Ruers TJ, van Riel P. Are patients' judgments of health status really different from the general population? Health Qual Life Outcomes 2011; 9: 31. (doi: 10.1186/1477-7525-9-31) (PMID: 21569351)

5. Denisov AP, Babenko Al, Kun OA, Banyushevich IA. Banyushevich Medical and social aspects of formation of health of young children. Omsk, Russia: Sibirskiy Gosudarstvennyy Universitet Fizicheskoy Kul'tury i Sporta, 2015; 70 p. Russian

6. Maheswaran J, Petrou S, Ris K, Stranges S. Evaluation of the EQ-5D utility values of the main behavioral risk factors for health in England. $J$ Epidemiol Community Health 2013; 67(2):172-180. (doi: 10.1136/jech2012-201019) (PMID: 22844084)

7. Lezwijn J, Wagemakers A, Vaandrager L, Koelen M, van Woerkum C. Planning in Dutch health promotion practice: a comprehensive view. Health Promot Int 2014; 29(2): 328-338. (doi: 10.1093/heapro/das051) (PMID: 23014261)

8. Health care in Russia - 2014. Statistical Yearbook. Rosstat. Moscow, Russia: Statistika Rossii, 2014; 378 p. Russian

9. Statistical Yearbook - 2014. Statistical Yearbook. Rosstat. Moscow, Russia: Statistika Rossii, 2014; 693 p. Russian

10. The International Statistical Classification of Diseases and Related Health. Tenth revision. Moscow, Russia: Meditsina, 1995; 170 p. Russian

11. Byuyul' A, Tsefel' P. SPSS: art information processing. The analysis of statistical data and restore hidden patterns: a translation from the German language. Saint Petersburg, Russia: Diasoftyup LLC, 2005; 608 p. Russian

12. Shabunova AA. Population health in Russia: the state and dynamics. Vologda, Russia: Institute of Socio-Economic Development of Territories of Russian Academy of Sciences, 2010; 176 p. Russian

13. Smagulov NK, Azhimetova GN. The role of environmental factors in shaping the health of the population. Mezhdunarodnyy Zhurnal Eksperimental'nogo Obrazovaniya 2013; 11(1): 57-60. Russian
14. Wilson R, Derrett S, Hansen P, Langley J. Retrospective evaluation versus population norms for the measurement of baseline health status. Health Qual Life Outcomes 2012; 10: 68. (PMID: 22698368) (doi: 10.1186/1477-7525-10-688)

15. Robine JM, Cambois E, Nusselder W, Jeune B, Oyen HV, Jagger C. The joint action on healthy life years (JA: EHLEIS). Arch Public Health 2013 71: 2. (doi: 10.1186/0778-7367-71-2) (PMID: 23379576)

\section{Authors:}

Vera A. Pogodina - MD, PhD, Associate Professor, Department of Hygiene and Ecology, Novosibirsk State Medical University, Novosibirsk, Russia.

Evgeniy A. Babenko - MD, PhD, Senior Researcher, Laboratory of Strategic Planning in Health Care, Research Institute for Complex Problems of Hygiene and Occupational Diseases, Novokuznetsk, Kemerovo Region, Russia.

Natalia A. Gusel'nikova - MD, Researcher, Laboratory of Strategic Planning in Health Care, Research Institute for Complex Problems of Hygiene and Occupational Diseases, Novokuznetsk, Kemerovo Region, Russia.

Anatoliy I. Babenko - MD, DSc, Professor, Head of Laboratory of Strategic Planning in Health Care, Research Institute for Complex Problems of Hygiene and Occupational Diseases, Novokuznetsk, Kemerovo Region, Russia. 